Igor Abramovych

advisor to the Directorate

Modern Art Research Institute of the National Academy of Arts of Ukraine
Ігор Абрамович

радник директора

Інституту проблем сучасного мистецтва

НАМ України

info@art-agent.com.ua +38 (050) 348-87-80 orcid.org/0000-0003-3404-2375

\title{
Contemporary Ukrainian Art and Collecting of 1991-2018
}

\author{
СУЧАСНЕ УКРАÏНСЬКЕ МИСТЕЦТВО \\ ТА КОЛЕКЦІОНУВАННЯ ВПРОДОВЖ 1991-2018 РОКІВ
}

\begin{abstract}
Summary. Since works of art are always investments not only in "emotional intelligence", but also in "value-artistic component", the goal of the article is to trace the formation of interaction between the creation of works of modern Ukrainian art and their collecting during Independence. Collecting works of art in Ukraine of the time indicated does not have comprehensive coverage. However, some recently published materials, allow us to present the general features of the formation of the institution of collecting in Ukraine. These publications have become the key basis for the study. It is shown that the initial motivation of collectors can be different: someone begins to simply collect "what they like", and this irresistible attraction grows into the creation of an impressive collection, and with its formation, the collector's preferences are also improved. Someone approaches art from the point of view of its material value, recognizing in collection a reasonable investment guaranteed against losses. Someone is engaged in collecting from the standpoint of patronage, seeking to support artists and development of art in general. But in any of these options there is, more than certainly, a plentiful cultural harvest in the future. Not aiming at a comprehensive consideration of the problem of collecting works of contemporary art in Ukraine, the article is designed in the mode of essay to present the main, most significant phenomena in the Ukrainian museum. They are aimed, firstly, at the actual fixation of artistic phenomena by collecting artistic artifacts, a holistic view of the emergence of modern Ukrainian art in the variety of its visual ideas, creative directions, "visual" and "mental" preferences and artistic positions, and thirdly, to establish a factual basis for understanding the phenomenon of art history of Ukrainian art of the 20th-21st centuries in the context of the global art movement.

Keywords: contemporary Ukrainian art, art of the 20th-21st centuries, art collection, Gradobank collection, Igor Voronov collection, Victor Pinchuk collection, Firtash Foundation, Saatchi gallery.
\end{abstract}

Problem statement. Since the beginning of Perestroika and subsequently, after gaining Independence, artistic processes intensify in Ukraine: a number of interesting artists arises, as well as various groups, associations, and unions. Some of them operated in the 1990s, some are still active, including New Wave artists and Fast Reaction Group, legendary Fine Art Reserve, Kyiv squats (Paris Commune squat etc.), groups R.E.P, SOSka, Open Group, and others. "Artistic geography" proves to be broad: Kyiv and Kharkiv, Odesa and Lviv, Kherson, Dnipro, Uzhhorod and Ukrainian-born expatriate artists.

That was when art became most prominent marker of social and political changes, happening in Ukraine at the time. Through their creative experiments with the new forms of presentations for their works, young artists set grounds for emergence of the new infrastructure of art, for formation of independent art criticism, unions of artists, galleries, patrons of the arts, and later-corporate collecting. Among latter the foremost was the Gradobank collection [5; 8]: marked with profound artistic value. It astounds with highly professional approach to expertise and includes the most interesting phenomena of contemporary art.

As the works of art are always investments not only in "emotional intellect", but also in "value-of-art", the aim of this study is to trace interaction between creation of contemporary Ukrainian art and its collecting during the Independence years.

Analysis of recent research works and publications. It should be noted, that art collecting of the 19912018 has not been subject to comprehensive examination. While collecting (and partly patrons of the arts) were studied within the history of culture of the previous century (at least in Russian Empire) (see [4]), contemporary collecting has been almost completely neglected. However, some recently published materials allow drawing general trends of the institution of collecting in Ukraine. These publications set grounds for the current research.

Significance of collecting in forming a cultural archive. According to the definition by N. Dmitrieva, art is one of the oldest attributes of human existence, "older than state and property, older than other complicated relations and feelings, including the sense of individuality that formed much later, within developed and differentiated human collective" [6, p. 13]. Therefore, collecting is and has always been one of the main ways to invest in art.

Initial motivations of the collectors may be different: some start acquiring items "to my liking" and later this irresistible drive turns into forming a vast collec- 
tion, the process that itself refines the tastes of a gatherer. Some approach art from the point of view of its financial value, seeing collecting as the most farseeing no-loss guaranteed investment. Some, being patrons of the arts, seek to support artists and art generally. Still, in the future each of these variants will certainly be fruitful for the cultural field.

"Obsession" is the most common word to describe collector's instinct. It comes along with the "fixed idea", "exhibitionism", and "self-exaltation". Collecting is often seen as a pathological attempt to control the turmoil in personal life or a way to overcome death. Sigmund Freud, an avid antique collector himself, labeled collecting as the "compensation of loss", and Walter Benjamin, an eager bibliophile, noted that, "The most profound enchantment for the collector is the locking of individual items within a magic circle in which they are fixed as the final thrill, the thrill of acquisition, passes over them" [2, p. 56]. In 1968, radically for his time, French philosopher Jean Baudrillard ridiculed collecting as a mean, with which consumption society substitutes universal human values and relations with material objects.

Gathering may be considered both an ailment and a therapy. Renowned English bibliophile William Carew Hazlitt charts his bibliomania as "cacoethes", stressing, at the same time, that collecting "is an inborn and indestructible human trait". The idea of obsessive collecting as an instinct is rather widespread. "When collecting is nothing else than rage, than this is that rage that makes a human” [2, p. 24].

First museum collections of Ukraine based on private collections of prominent patrons of the arts. Private collectors have always played a crucial role in replenishing museum collections. Many of the world famous museums' collections were initiated from the donations of private gatherers.

Western private museums of contemporary art that were based on their founders' collections (such as Solomon R. Guggenheim Museum in New York, Museum Ludwig in Cologne, Saatchi Gallery in London) are one of the most influential and established institutions in the world of contemporary art. National Art Museum of Ukraine is also one of such institutions, as it was founded in 1899 under Russian Empire and funded both by imperial government and by Ukrainian Tereshchenko family [7]. Being one of the largest and oldest museums in the country, National Art Museum of Ukraine formed its collection based on donations from Bohdan Khanenko, Tereshchenko family, Vikentiy Khvoika, Mykhailo Biliashivsky, and others.

The core of Bohdan and Varvara Khanenko National Museum of Arts (formerly Kyiv Museum of Western and Oriental Art) [10] collection was formed of the private collections of Khanenko family and of Vasyl Schavynsky (1868-1924), a chemist and a scholar. High artistic value of Khanenko collection was obvious even then, on the edge of the $20^{\text {th }}$ century. National Museum "Kyiv Picture Gallery” (till March 2017-Kyiv National Museum of Russian Art [12]) is housed in a building, once (since the late $19^{\text {th }}$ through the early $20^{\text {th }}$ century) owned by Fedir Tereshchenko and later confiscated along with all its belongings by the Soviet authorities. Kyiv Picture Gallery opened there in 1922. The core collection consisted from the collections of Kyiv industrialists and patrons of the arts-Tereshchenko family. Original exposition included over 200 artworks, turning to 300 by the 1928 .

It is obvious that collecting art is mostly for welloff people. During the late $19^{\text {th }}$ century and first decades of the $20^{\text {th }}$ among them, not lacking taste and interest in art, was Nikola Tereshchenko (1819-1903), patron of the arts and one of the founders of Kyiv and Glukhiv museums. His private collections laid basis for a few future Kyiv museums. His daughter Varvara along with her husband Bogdan Khanenko founded their own museum and initiated embroidery workshops in Kyiv region. Tereshenko’s son, Ivan Nikolovich (1854-1903), member of Kyiv city Duma, collector, sugar manufacturer and landowner, received wide recognition as a patron of the arts by financially supporting Mykola Murashko, head of the Kyiv Drawing School.

Bogdan Khanenko (1849-1917), a collector of Ukrainian antiquities and artworks, member of the Imperial Duma and industrialist, son-in-law of Nikola Tereshchenko, along with his wife assembled a significant collection of artworks and books on art. It is thanks to these historical figures that Kyiv now has strong collections of classical Western European, Russian and Oriental art, which eventually shaped the cultural silhouette of the city and of Ukrainian culture generally. As astutely pointed out by O. Bokhanov about Russian collectors and philanthropists Pavel and Sergey Tretyakov, Savva Morozov, and Savva Mamontov, “despite being capitalists by birth and by occupation, they managed to rise above their classes and consciously acted to achieve nationwide goals” [4, p. 4]. That is equally true regarding Tereshchenko family, as well as the Khanekos or Pavlo Pototsky (who was not only General of the Artillery, but also a military historian [3]).

Role of contemporary art collecting in topical cultural processes. Collecting contemporary artworks is a fascinating and gratifying affair, since it turns out to be an exact documenting of the era, contemporary to the collector himself, with him being both its witness and participant. Collector observes and memorizes, documents it for generations to come, taking part in creation of its artistic myth that is much more meaningful and significant than political myth. Not to say-more lasting.

By acquiring the works of his peers now, collector simultaneously gets something more valuable than investment potential: it offers a rare and exiting opportunity of communication with outstanding, extremely interesting personalities. To live in the same historical period with the artists, whose works you collect, to follow their impressions and thoughts that are reflection of unique experience, interact with them, discuss new ideas-is an extraordinary pleasure and historic chance.

Currently, the collectors' role in contemporary Ukraine is evident and significant. Naturally, according to marketing laws, the best pieces from key contemporary artists end up in collections of leading collectors. That is how current artistic situation gets illustrated, how true reference points of values and predictive future events at the contemporary art scene are revealed. In such a natural way, the foundation for potential museum of contemporary art is being set. The necessity to exhibit these works in a public space becomes obvious, as they deserve not only to be carefully preserved by art collectors, but also to receive public acclaim.

With critical praise and proper presentation, this 
foundation opens up possibility to contemplate iconic, program art works of previous decades that are currently parts of private collection and are inaccessible to general public; it could also be foundation for so much needed, yet nonurgent museumization of contemporary Ukrainian art.

That would be museumization, based on European and American models of contemporary museum [17], with the accent on the widest and pithy communication for the sake of development of world culture and not only on mechanical conservation and presentation of cultural heritage.

Contemporary Ukrainian collections. A number of strong collections of contemporary art are currently being built in Ukraine, including the ones of: Voronov Art Foundation, PinchukArtCentre, Stedley Art Foundation, Brovdi Foundation, Zenko Foundation, Abramovych ART, Petro Bagriy, Liudmyla Bereznytska, Andriy Berezniakov, Natalia and Serhiy Vakulenko, Igor Vlasov, Anatoliy Dymchiuk, Oksana and Mykhailo Kalitsky, Yevhen Karas, Yuriy Kogutiak, Oleg Krasnoselskyi, Oksana Kurinna, Liudmyla and Andriy Pyshny, Andriy Suprunenko, Victoria Tigipko, Borys Lozhkin and Nadiya Shalomova, Volodymyr Shpilfogel, Serhiy and Yevheniya Shudra.

The following are some of the most important collections of contemporary art in Ukraine.

Gradobank. The collection assembling started in 1991 and (according to the court ruling) consists of 785 artefacts, including paintings by classics of foreign (Renoir, Degas, Toulouse-Lautrec, Kandinsky, Picasso, Dali, Miró, Léger) and Ukrainian art (the very best of Ukrainian painting tradition: from Shevchenko to Bohomazov), as well as the pieces by the starts of Ukrainian contemporary art (Kavsan, Kryvolap, Roytburd, Savadov, Senchenko, Szilvashi, Tistol, etc.). Estimated value of the collection as of 2014 was over $€ 52$ million, according to the audit results by the Art Analytics company, commissioned by Gradobank [5; 8].

In 1996 Gradobank-one of the leading banks in the country-suffered a misfortune; seeking for emergency rescue, the bank took a loan of $\$ 5$ million from the National Bank of Ukraine with paintings collection as a collateral. In 2000 Gradobank, that failed to repay the credit, was declared bankrupt. Its collection had to be auctioned, however its actual value was far above the estimate (up to 2015 Prosecutor's General Office of Ukraine operated the estimate number (from 1996) of $\$ 5,2$ million). Therefore, the credit would not only be repaid with National Bank receiving the funds; it was probably that investors of the bankrupt bank would get them as well.

Auction never took place: Verkhovna Rada of Ukraine banned such auctions back in 1998 and in 2004 voted for the law that declared Gradobank collection a national cultural heritage belonging to the state.

Eventually, in 2005 an agreement was reached, according to which the debt of Gradobank to National Bank of Ukraine was paid off from the state budget in exchange of Gradobank collection. National Bank of Ukraine should convey the collection to the funds of National Art Museum of Ukraine. In 2008 Constitutional Court of Ukraine declared unconstitutional some articles of the Law of Ukraine "On Transferring the Fine Art Collection of Joint Stock Company 'Gradobank' to the State Ownership” dated June 24, 2004; transferring of the collection to the state ownership was considered unlawful, however the collection received a status of an object of national cultural heritage (it cannot cross the state border). In 2016, twelve years after the law was passed, the National Art Museum of Ukraine finally presented unique part of the Gradobank collection [15; 16]: works of Ukrainian art from the late 1980s until 1995: Leaving and Returning exhibition included some of the 785 paintings, handled to the museum according to the court ruling. Leaving and Returning was the title of a 1989 painting by Glib Vysheslavsky. Eduard Dymshyts, Candidate in Art Studies, collector, curator of private collections and former director of the Gradobank National Art Gallery, accompanied his creation through good and bad times. He assembled painting collections for Gradobank, Ometa-Inster insurance company, First Ukrainian International Bank, as well as many private collections, for instance the one of businessman Kostyantyn Grygorishin [8].

Igor Voronov collection. Igor Voronov is one of the most well-known and generous philanthropists in Ukraine. After fortunate sale of his grand insurance company Credo-Classic to the Austrian buyers, he devoted himself to art completely. Voronov is an owner of one of the most significant collections of sculpture and fine art in the Western Europe and a founder of Voronov Art Foundation.

Today Voronov focuses mainly on art investment. He set his mind on collecting works of art back in early 1900s, when he received two artworks (by Bovkun and Poderviansky) from his business partners as a gift. "And by the mid-1900s it became clear to me that I always appreciated art above all”, says Voronov. All his charitable projects are related to fine art-through his namesake Voronov Art Foundation (founded in 2008) that also organizes exhibitions based on his private collection. Thanks to Igor Voronov, Ukrainians have unique opportunity to see authentic pieces by Oleksandr Archipenko, Constantin Brâncuși, Edgar Degas, Alberto and Diego Giacometti, Amadeo Modigliani, Pablo Picasso, Demetre Chiparus, and other world-famous masters. Further, Voronov acquired two thousand works of contemporary Ukrainian artists: Serhiy Bratkov, Oleksander Ginilitsky, Oleg Golosiy, Dmytro Dulfan, Illya Yusupov, Pavlo Kerestei, Oleg Kulyk, Yuriy Leiderman, Pavlo Makov, Roman Minin, Mykola Matsenko, Boris Mikhailov, Oleksandr Roytburd, Stepan Riabchenko, Arsen Savadov, Georgiy Senchenko, Andriy Sagaidakovsky, Tyberiy Szilvashi, Yuriy Solomko, Oleg Tistol and Illya Chichkan. Collector Dmytro Andriyevskyi collaborates as a partner in many of Voronov projects. Igor Voronov's collection of sculpture is assessed as one of the most valuable in Ukraine (Figure by Alberto Giacometti is estimated to be the highestpriced artefact of the collection, worth $\$ 10$ million) [9].

Victor Pinchuk, Ukrainian entrepreneur, politician, billionaire and philanthropist, founder of the investment and consulting company EastOne and charitable organization Victor Pinchuk Foundation. PinchukArtCentre, founded by him, is an international centre for contemporary art of the $21^{\text {st }}$ century, an open platform for artists, art and society.

His First Collection is an exhibition of Ukrainian art, held in the Central House of Artists during 11.2215.5.2003. Some of the pieces, presented there, were acquired for the collection of then projected Museum 
of Contemporary Art (that eventually ended up being PinchukArtCentre). Victor Pinchuk collection incorporates artworks by many Ukrainian painters, as well as Ukrainian-born or Ukrainian-based artists: Serhiy Onufriev, Serhiy Bratkov, Oleksander Gnilitsky, Oleg Golosiy, Dmytro Dulfan, Illya Isupov, Pavlo Kerestei, Oleg Kulik, Yuriy Leiderman, Pavlo Makov, Mykola Matsenko, Boris Mikhailov, Oleksandr Roytburd, Arsen Savadov, Georgiy Senchenko, Andriy Sagaidakovsky, Tiberiy Szilvashi, Yuriy Solomko, Serhiy Solonsky, Oleg Tistol, Illya Chichkan, Masoch Fund art association, etc. 1991 (year of Independence proclamation) has been chosen as a reference point for building up Ukrainian part of the collection. Chronologically the collection also covers main art trends of the 1980s that genealogically preceded the topical art of the 1990s and revealed the trends that eventually formed Ukrainian contemporary art: hyperrealism, pictorial transavanguard, Odesa conceptual art, Kharkiv School of Photography, Lviv neoexpressionism.

Later on the collection experienced an inflow of internationally acclaimed works by the stars of the global art scene. Victor Pinchuk has pieces by Jeff Kuns, Takashi Murakami, Andreas Gursky, and others in his private collection. Pinchuk possesses one of the largest collections of works by Damien Hurst.

Firtash Foundation. Days of Ukraine in the United Kingdom, held in London on 17-19 November 2013 became a precedent of successfully organized Ukrainian practices of a kind. Within the program of a festival, initiated and organized by Firtash Foundation, landmark city locations (including London Public Library, Potters Fields Park and Saatchi Gallery) hosted several cultural events: literary readings, musical concerts, haute couture fashion shows, exhibition of contemporary Ukrainian artists. Curators' and artists' names speak for themselves: musician and cultural figure Oleg Skrypka, Dr. Rory Finnin, Director of Cambridge Ukrainian Studies Program, writer and literature researcher Oksana Zabuzhko, head of the Ukrainian Fashion Week Iryna Danilevska, art dealer and exhibition organizer Igor Abramovych. The art show included works by 25 artists: Nazar Bilyk, Matviy Vaisberg, Artem Volokitin, Igor Gusev, Oleksandr Zhyvotkov, Oleksiy Zolotariov, Zhanna Kadyrova, Pavlo Kerestei, Oleksandr Klymenko, Anatoliy Kryvolap, Pavlo Makov, Maksym Mamsikov, Mykola Matsenko, Roman Minin, Vinny Reunov, Oleksandr Roytburd, Stepan Riabchenko, Arsen Savadov, Oleksiy Sai, Victor Sydorenko, Tiberiy Szilvashi, Maryna Skugareva, Yuriy Solomko, Oleg Tistol, and Vasyl Tsagolov.

The author of the current article, who also organized a number of exhibitions that presented oeuvre of contemporary Ukrainian artists, and who actively promotes contemporary Ukrainian art in the global art space, has curated the project. According to my worldview, to present Ukrainian art as an integral phenomenon, as an endless process with its own logic of development-is one of the main tasks that would lead to integrating Ukraine in the global cultural situation. Therefore, the key trends in development of Ukrainian art of the last decades caused the artists selection for the exhibition.

The older generation represent painting upsurge of the 1990s that came after general social, political and cultural liberalization following the collapse of the USSR. This upsurge took two main courses that defined the face of Ukrainian art of the decade: figurative postmodern art and abstract neo-avant-guarde. Almost all key figures of these two trends, who shaped the artistic development of independent Ukraine from its roots, were included in the project. Younger participants of the exhibition are outstanding artists of the 2000s that partly follow the direction, set by their older peers, however choosing another diapason of forms and senses, selecting other media.

Presented works reflect the specifics and cultural autonomy of Ukraine with its accents and unique hierarchy of cultural values.

The exhibition of Ukrainian artists at the Saatchi Gallery [11] - one of the world famous and best-visited-is an unprecedented art event for Ukraine; and it would be no exaggeration to say-strategic. For the first time an international institution of such high level hosted a large-scale exhibit of works by contemporary Ukrainian artists from the private collection of Ukrainian collector. This highly-attended exhibition proved existence of contemporary Ukrainian art phenomenon to the international audience. Popularity of the exhibition is partly caused by its coincidence in time with the Frieze Art Fair-one of the greatest international fairs of contemporary art that annually gathers actors of the world art scene and art business. According to the Saatchi Gallery statistics, during the Frieze Art Fair the number of gallery visitors doubles.

Days of Ukraine in London became the first step in international representation of Ukrainian cultural situation and in creation of an image of a country, with the adequate progressive approach used, targeted on the worldwide artistic experience.

The projects, realized during the Days of Ukraine, were meant to familiarize viewers with contemporary Ukrainian art, thus they were nor conceptual, nor analytical. It was the very first, however strategic and highly important for the further promotion attempt that opened new ways to integrate Ukrainian art, philanthropy and art collecting in all its diversity of manifestations and potential into the global art and art market.

One more aspect to be mentioned is compiling and publishing catalogs, themed by the certain "project" or, on the contrary, pronouncedly different and diverse in contents [1; 13]. For contemporary Ukrainian artists such catalogs become a unique form of not so much documenting, as of representing their works. However, this requires a separate detailed study.

Conclusions. Not setting a goal to thoroughly examine collecting contemporary works of art in Ukraine (the task, unfeasible in a journal publication), the presented writing aims to outline primary, most significant phenomena in Ukrainian museum sphere. They are oriented, first of all, on concurrent documenting of artistic phenomena and events by collecting artistic artefacts; second of all, on forming an integral concept of development of contemporary Ukrainian art in all the diversity of its visual ideas, trends, "visual" and "conscious" likings and artistic standpoints; third of all, on setting a fact foundation for further studies of phenomenon of contemporary Ukrainian art of the $20^{\text {th }}$ and $21^{\text {st }}$ centuries within the context of global art movement. 


\section{Literature}

1. 25 років присутності: Каталог: У 2 т. Київ: ІПСМ НАМ України, 2016. Т. 1. 184 с.; Т. 2.172 с.

2. Бак Л., Грир Д. Искусство в собственность: Настольная книга коллекционера современного искусства / Пер. с англ. Москва: Фэйс Фэшн, 2008. 336 с.

3. Білокінь С. І. Музей України (Збірка П. Потоцького): Дослідження, матеріали. Київ: Ін-т історії України НАН України, 2006. 476 с.

4. Боханов А. Н. Коллекционеры и меценаты в России. Москва: Наука, 1989. 192 с.

5. Градобанк відсудив у держави картини Ренуара, Пікассо і Далі // Лівий берег. Культура. - Режим доступу: https://ukr.lb.ua/culture/2015/12/24/324353-_gradobank_vidsudiv_derzhavi_kartini.html

6. Дмитриева Н. А. Краткая история искусств. Москва: Искусство, 1985. 319 с.

7. Донік О. М. Терещенки // Енциклопедія історії України: У 10 т. Київ: Наук. думка, 2013. Т. 10: Т-Я. С. 58. 8. Едуард Димшиц про створення колекції Градобанку // Мітєц: Сучасне мистецтво України. — Режим доступу: http://mitec.ua/category/artists/dyimshits-eduard/

9. Игорь Воронов: «Мне претит, когда некоторые люди рассматривают коллекционирование с точки зрения бизнеса или пиара» // Art Ukraine. - Режим доступу: http://artukraine.com.ua/a/igor-voronovquotmne-pretit-kogda-nekotorye-lyudi-rassmatrivayut-kollekcionirovanie-s-tochki-zreniya-biznesa-ilipiaraquot/\#.Wp-Qnk5P1WCQ

10. Історія музею // Офіційний сайт Музею Ханенків. - Режим доступу: http://khanenkomuseum.kiev.ua/istoriya-muzeyu/

11. Маценко Н. Неможливе можливе: українське мистецтво в Saatchi Gallery // Art Ukraine. 2013. C. $162-165$.

12. Музей російського мистецтва має бути перейменовано. Інтерв’ю з Оленою Терещенко // Громадське радіо. - Режим доступу: https://hromadskeradio.org/programs/rankova-hvylya/muzeyrosiyskogo-mistectva-maie-buti-pereymenovano-aktivistka

13. Музейне зібрання: Українське сучасне мистецтво 1985-2015 (3 приватних колекцій). Київ: Мистецький Арсенал, 2015. 312 с.

14. Національний музей Тараса Шевченка. Офіційна сторінка. - Режим доступу: http://museumshevchenko.org.ua/

15. Національний художній музей України. Офіційна сторінка. - Режим доступу: http://namu.kiev.ua/ 16. У Національному художньому музеї України діє виставка картин з колекції Градобанку «Йду іповертаюсь» // Міністерство культури України. Офіційний сайт. - Режим доступу: http://mincult.kmu.gov.ua/control/uk/publish/-article?art_id=245172716\&cat_id=244913751

17. Яковець I. О. Художній музей XXI століття. Черкаси: Видавець О. Вовчок, 2016. 464 с.

\section{References}

1. 25 rokiv pry`sutnosti: Katalog: U 2 t. Ky`yiv: IPSM NAM Ukrayiny`, 2016. T. 1.184 s.; T. 2.172 s.

2. Bak L., Grir D. Iskusstvo v sobstvennost: Nastolnaya kniga kollektsionera sovremennogo iskusstva / Per. s angl. Moskva: Feys Feshn, 2008. 336 s.

3. Bilokin`S. I. Muzej Ukrayiny` (Zbirka P. Potocz `kogo): Doslidzhennya, materialy`. Ky yiv: In-t istoriyi Ukrayiny`NAN Ukrayiny`, 2006. 476 s.

4. Bohanov A. N. Kollektsioneryi i metsenatyi v Rossii. Moskva: Nauka, 1989. $192 \mathrm{s.}$

5. Gradobank vidsudy `v u derzhavy` karty`ny`Renuara, Pikasso i Dali // Livy `j bereg. Kul `tura. — Rezhy `m dostupu: https://ukr.lb.ua/culture/2015/12/24/324353-_gradobank_vidsudiv_derzhavi_kartini.html

6. Dmitrieva N. A. Kratkaya istoriya iskusstv. Moskva: Iskusstvo, 1985. $319 \mathrm{~s}$

7. Donik O. M. Tereshhenky`// Ency`klopediya istoriyi Ukrayiny`: U 10 t. Ky`yiv: Nauk. dumka, 2013. T. 10: T-Ya. S. 58.

8. Eduard Dy`mshy`cz pro stvorennya kolekciyi Gradobanku // Mityecz: Suchasne my`stecztvo Ukrayiny`. — Rezhy`m dostupu: http://mitec.ua/category/artists/dyimshits-eduard/

9. Igor Voronov: «Mne pretit, kogda nekotoryie lyudi rassmatrivayut kollektsionirovanie s tochki zreniya biznesa ili piara» // Art Ukraine. — Rezhim dostupu: http://artukraine.com.ua/a/igor-voronov-quotmne-pretitkogda-nekotorye-lyudi-rassmatrivayut-kollekcionirovanie-s-tochki-zreniya-biznesa-ili-piaraquot/\#.WpQnk5P1WCQ

10. Istoriya muzeyu // Oficijny`j sajt Muzeyu Xanenkiv. - Rezhy`m dostupu: http://khanenkomuseum.kiev.ua/istoriya-muzeyu/

11. Macenko N. Nemozhly`ve mozhly`ve: ukrayins `ke my`stecztvo v Saatchi Gallery // Art Ukraine. 2013. C. 162-165.

12. Muzej rosijs `kogo my`stecztva maye buty` perejmenovano. Interv’yu z Olenoyu Tereshhenko // Gromads `ke radio. - Rezhy`m dostupu: : https://hromadskeradio.org/programs/rankova-hvylya/muzeyrosiyskogo-mistectva-maie-buti-pereymenovano-aktivistka

13. Muzejne zibrannya: Ukrayins `ke suchasne my`stecztvo 1985-2015 (Z pry`vatny`x kolekcij). Ky`yiv: My`stecz`ky`j Arsenal, 2015. 312 s.

14. Nacional`ny`j muzej Tarasa Shevchenka. Oficijna storinka. - Rezhy`m dostupu: http://museumshevchenko.org.ua/

15. Nacional `ny j xudozhnij muzej Ukrayiny`. Oficijna storinka. — Rezhy`m dostupu: http://namu.kiev.ua/ 16. U Nacional `nomu xudozhn `omu muzeyi Ukrayiny`diye vy`stavka karty`n z kolekciyi Gradobanku "Jdu i povertayus`» // Ministerstvo kul `tury`Ukrayiny`. Oficijny`j sajt. - Rezhy`m dostupu: http://min- 
cult.kmu.gov.ua/control/uk/publish/-article?art_id=245172716\&cat_id=244913751

17. Yakovecz`I. O. Xudozhnij muzej XXI stolittya. Cherkasy`:Vy`davecz`O. Vovchok, 2016. 464 s.

\author{
Ігор Абрамович \\ Сучасне українське мистецтво та колекціонування впродовж 1991-2018 років
}

Оскільки твори мистецтва - це завжди інвестиції не лише в «емоційний інтелект», а й у «вартіснохудожню складову", метою цією студії було простеження формування взаємодії між творенням сучасного українського мистецтва та колекціонуванням його творів упродовж часу Незалежності. Колекціонування творів мистецтва в Україні зазначеної доби не має комплексного висвітлення. Втім, деякі матеріали, оприлюднені останнім часом, дозволяють уявити загальні риси формування інституту колекціонування в Україні. Саме ці публікації стали джерельною базою для презентованої студії. Показано, що вихідна мотивація колекціонерів може бути різною: хтось починає просто збирати «те, що до вподоби», і цей дедалі непоборніший потяг переростає у створення значної колекції, а з їі формуванням вдосконалюються й уподобання збирача. Хтось підходить до мистецтва 3 точки зору його матеріальної цінності, розпізнавши у колекціонуванні найрозумніше капіталовкладення, гарантоване від збитків. Хтось займається колекціонуванням з меценатських позицій, прагнучи підтримати митців і розвиток мистецтва в цілому. Але у будь-якому 3 цих варіантів міститься, більш ніж напевно, рясний у прийдешньому врожай з рілля культури. Не ставлячи за мету всебічний розгляд проблеми колекціонування творів сучасного мистецтва України, стаття покликана у начерковому режимі презентувати основні, найбільш значущі явища в українському музейництві, що спрямоване, по-перше, на актуальну фіксацію художніх явищ шляхом колекціонування мистецьких артефактів, по-друге, на формування цілісного погляду на становлення сучасного українського мистецтва в розмаїтості його візуальних ідей, творчих напрямів, «зорових» і “розумових» уподобань і художніх позицій, по-третє, на створення фактологічного підгрунтя для мистецтвознавчого осмислення явища українського мистецтва $\mathrm{XX}-$ XXI століть у контексті світового мистецького руху.

Ключові слова: сучасне українське мистецтво, мистецтво XX-XXI століть, мистецька колекція, колекція «Градобанку», колекція Ігоря Воронова, колекція Віктора Пінчука, Firtash Foundation, галерея «Saatchi».

\title{
Игорь Абрамович \\ Современное украинское искусство и коллекционирование 1991-2018 годов
}

Поскольку произведения искусства - это всегда инвестиции не только в «эмоциональный интеллект», но и в «ценностно-художественную составляющую», цель статьи - проследить формирование взаимодействия между созданием произведений современного украинского искусства и их коллекционированием на протяжении Независимости. Коллекционирование произведений искусства в Украине указанного времени не имеет комплексного освещения. Однако некоторые материалы, опубликованные в последнее время, позволяют представить общие черты формирования института коллекционирования в Украине. Именно эти публикации стали ключевой базой исследования. Показано, что исходная мотивация коллекционеров может быть разной: кто-то начинает просто собирать «то, что нравится», и это непреодолимое влечение перерастает в создание внушительной коллекции, а с ее формированием совершенствуются и предпочтения собирателя. Кто-то подходит к искусству с точки зрения его материальной ценности, распознав в коллекционировании разумное капиталовложение, гарантированное от убытков. Ктото занимается коллекционированием с точки зрения меценатства, стремясь поддержать художников и развитие искусства в целом. Но в любом из этих вариантов содержится, более чем наверняка, обильный в будущем культурный урожай. Не ставя целью всестороннее рассмотрение проблемы коллекционирования произведений современного искусства в Украине, статья призвана в режиме очерка представить основные, наиболее значимые явления в украинском музейництве, направленные, во-первых, на актуальную фиксацию художественных явлений путем коллекционирования художественных артефактов, во-вторых, на формирование целостного взгляда на становление современного украинского искусства в разнообразии его визуальных идей, творческих направлений, «зрительных» и «умственных» предпочтений и художественных позиций, в-третьих, на создание фактологического основания для искусствоведческого осмысления явления украинского искусства XX-XXI веков в контексте мирового художественного движения. Ключевые слова: современное украинское искусство, искусство XX-XXI веков, художественная коллекция, коллекция «Градобанка», коллекция Игоря Воронова, коллекция Виктора Пинчука, Firtash Foundation, галерея «Saatchi». 